J. Dairy Sci. 92:469-476

doi:10.3168/jds.2008-1293

(c) American Dairy Science Association, 2009.

\title{
Effect of the inclusion of whole citrus in the ration of lactating ewes on the properties of milk and cheese characteristics during ripening
}

\author{
D. P. Jaramillo, ${ }^{*}$ T. García, ${ }^{*}$ M. Buffa, ${ }^{*}$ M. Rodríguez,† B. Guamis, ${ }^{*}$ and A. Trujillo*1 \\ ${ }^{*}$ Centre Especial de Recerca Planta de Tecnologia dels Aliments (CERPTA), XaRTA, XiT, Departament de Ciència Animal i dels Aliments, \\ Facultat de Veterinària, Universitat Autònoma de Barcelona, 08193 Bellaterra (Spain) \\ †Departamento de Ciencia Animal, Universidad Politécnica de Valencia, 46010 Valencia, Spain
}

\section{ABSTRACT}

The effect of including citrus fruits $(\mathrm{CF})$ in the rations of dairy ewes on the milk characteristics and biochemical changes of cheeses during ripening was evaluated. For this purpose, 48 lactating ewes (Guirra breed) were divided into 4 homogeneous groups and fed with isoenergetic and isoprotein rations containing $\mathrm{CF}$ at $0,10,20$, and $30 \%$ on a dry matter basis in substitution of dry barley and pelleted beet pulp. During the experimental period, 3 batches of bulk milk were collected from each group and semi-hard cheeses were manufactured. Cheeses were sampled at 15, 30, and 60 $\mathrm{d}$ of ripening. Milk coagulation parameters and cheese yield were not negatively affected by the inclusion of CF in the ration. Physicochemical composition of cheeses at $60 \mathrm{~d}$ showed statistical differences for lower total solids and fat content of $30 \% \mathrm{CF}$ cheeses. Proteolysis of cheeses measured by water-soluble nitrogen and total free amino acids content was not influenced by the ration. Differences between rations with respect to free fatty acids were significant for medium- and long-chain free fatty acids, and therefore for total content, but differences did not show a trend related to the increase of $\mathrm{CF}$ in the diet. The inclusion of $\mathrm{CF}$ in the ration of lactating ewes up to levels of $30 \%$ did not negatively affect the properties of milk and the biochemical and sensory characteristics of cheeses.

Key words: citrus fruit, dairy ewe, milk coagulation, cheese ripening

\section{INTRODUCTION}

Spain is one of the main citrus fruit producers within the Mediterranean region, accounting for $\sim 5$ million tonnes of citrus (which includes oranges, tangerines, mandarins, and clementines) per year (FAOSTAT, 2006). This activity generates tons of residue compris-

Received April 23, 2008

Accepted September 23, 2008.

${ }^{1}$ Corresponding author: Toni.Trujillo@uab.es ing mainly whole fruit that is withdrawn from the market because of price regulations or poor quality. The use of this by-product for the feeding of Mediterranean livestock could be an alternative that contributes to reducing environmental problems, waste management costs, and dependence on grains for local livestock feeding.

Citrus by-products have been tested and offered as ruminant feeds mainly as fresh citrus pulp, citrus silage, or dried citrus pulp. According to a recent review by Bampidis and Robinson (2006), these residues can be used as a high energy source in the rations of ruminants during growth and lactation periods. Regarding small dairy ruminants, it has been observed that the inclusion of citrus by-products in the diet of animals has some effects on milk yield and composition. Fegeros et al. (1995) evaluated the inclusion of dried citrus pulp in the ration of lactating ewes and found that the use of up to $10 \%$ of this by-product did not reduce milk yield or fat content, but had an effect on milk fat composition. Other studies carried out by Volanis et al. (2004) demonstrated that the inclusion of ensiled sliced oranges in dairy ewe feed ( $3 \mathrm{~kg}$ per animal per day) caused a reduction of global milk yield and an increase of milk fat content; however, milk yield standardized at $6 \%$ fat was not influenced by diet. Recently, Piquer (2006) evaluated the inclusion of fresh citrus fruits in the diet of lactating ewes, reporting a reduction in the milk fat content relative to the inclusion of citrus in the $\operatorname{diet}(10,20$, and $30 \%$ on a DM basis); however, at the higher citrus level an increase of total milk yield was observed. Finally, Piquer (2006) recommends the use of citrus fruits for ewe feeding but with caution when animals present low body condition.

It is known that feeds offered to dairy animals can affect milk composition, and therefore milk properties and the quality of derived products. Several studies have described the influence of feed based on forages, grazing, or mixed rations on the characteristics of cheeses. Coulon et al. (2004) in their extensive review highlighted the effect of the type of forage, conservation method, grass quality, and botanical diversity on the 
Table 1. Ingredients of the experimental rations with $0,10,20$, and $30 \%$ of citrus fruits $(\mathrm{CF})$ fed to dairy ewes (expressed on a DM basis)

\begin{tabular}{lrrrr}
\hline & \multicolumn{4}{c}{ Ration } \\
\cline { 2 - 5 } Ingredient (g/d) & $0 \%$ CF & $10 \%$ CF & $20 \%$ CF & $30 \%$ CF \\
\hline Citrus fruit & 0 & 250 & 500 & 750 \\
Barley grains & 700 & 466 & 233 & 0 \\
Beet pulp & 270 & 180 & 90 & 0 \\
Soybean meal & 220 & 257 & 293 & 330 \\
Alfalfa hay & 1,000 & 1,000 & 1,000 & 1,000 \\
Barley straw & 260 & 260 & 260 & 260 \\
Molasses & 30 & 30 & 30 & 30 \\
Vitamin/mineral mixture & 74 & 74 & 74 & 74 \\
Total & 2,554 & 2,517 & 2,480 & 2,444 \\
\hline
\end{tabular}

sensory attributes of cheese. Furthermore, it has been reported that certain plants can transmit undesired flavors to milk and cheese (Urbach, 1990). Regarding the use of crop by-products in the diet of dairy small ruminants, most of the studies did not include the effect on milk technological properties and final cheese characteristics, which is important because their milk is mainly used for cheese manufacturing. The aim of this work was to evaluate the effect of increasing substitution of cereal grain and sugar beet pulp by citrus fruits $(\mathbf{C F})$ in the mixed rations of ewes on milk technological properties and ripened cheese characteristics.

\section{MATERIALS AND METHODS}

\section{Animals and Experimental Rations}

The 48 dairy ewes (Guirra breed) used in this study belong to the Animal Science Department of the Universidad Politécnica de Valencia. Ewes were managed to allow one parturition and concentrate lamb births within 2 and 3 wk. After weaning (wk 6 of lactation), ewes were milked mechanically twice daily. Prior to CF ration evaluation, ewes were subjected to a preexperimental period (wk 7 and 8 of lactation) where animals received a uniform ration based on cereal grains, pelleted beet pulp, soybean meal, alfalfa hay, and cereal straw. Then, ewes were distributed into 4 homogeneous groups of 12 animals equally balanced by parturition number and productive level, and control and $\mathrm{CF}$ rations were offered twice daily during the experimental period (wk 9 to 17 of lactation), allowing 1 wk for adaptation to diet before milk sampling.

The citrus used in this study was a variety of clementines (Citrus clementina) cultivated in the east of Spain with a harvest season that ranges from November to January. Fruits are characterized by their medium size (80-100 g per unit), good juice content, and absence of seeds (Piquer, 2006). Experimental rations contained fresh $\mathrm{CF}$ at 0 (control), 10, 20, and $30 \%$ in substitution of barley and beet pulp on a DM basis (Table 1). Rations were formulated to be isoenergetic (15.20 MJ per $\mathrm{kg}$ of $\mathrm{DM})$ and isoprotein $(\sim 250 \mathrm{~g}$ of digestible protein per $\mathrm{kg}$ of DM).

\section{Milk Sampling and Analysis}

Bulk milk samples $(\sim 10 \mathrm{~kg})$ corresponding to each experimental ration were obtained 3 times during the evaluation period at wk 13, 15, and 17 of lactation (total milk samples: 12). Samples comprised a mixture of milk from morning and afternoon milkings. Milk fraction for physicochemical analyses and SCC was stored at $4^{\circ} \mathrm{C}$ until analysis $(2-4 \mathrm{~h})$, whereas bulk samples for cheese production were held at 6 to $8^{\circ} \mathrm{C}$ and processed $\sim 15 \mathrm{~h}$ later at the pilot plant of the Universitat Autònoma de Barcelona.

Milk samples were analyzed for fat, total protein, CN, lactose, and TS, by infrared analysis (IDF 1996) using a MilkoScan FT-120 (Foss Electric, Hillerød, Denmark). The $\mathrm{pH}$ was measured using a $\mathrm{pH}$ meter (Crison Micro-pH 2001, Crison Instruments SA, Barcelona, Spain) and SCC was performed by a Fossomatic 5000 cell counter (Foss Electric).

\section{Cheese Making}

Cheeses were manufactured from pasteurized milk $\left(65^{\circ} \mathrm{C}\right.$ for $\left.30 \mathrm{~min}\right)$ following the procedure of Trujillo et al. (1999) with some modifications. Briefly, milk was heated to $32^{\circ} \mathrm{C}$ and $2 \%$ lactic starter (Lactococcus lactis ssp. lactis and Lactococcus lactis ssp. cremoris) and $0.35 \%$ (wt/vol) of $\mathrm{CaCl}_{2}$ were added. Twenty minutes later, $0.0375 \%$ ( $\mathrm{vol} / \mathrm{vol}$ ) of liquid chymosin (Maxiren 180, DSM Food Specialties, Barcelona, Spain) was added and coagulation was carried out at $32^{\circ} \mathrm{C}$ for 30 min. The resultant coagulum was cut into 8- to 10$\mathrm{mm}$ cubes and the curd was heated to $37^{\circ} \mathrm{C}$ for $15 \mathrm{~min}$ before whey drainage. The curd was then molded into pieces of $\sim 400 \mathrm{~g}$ and pressed in a pneumatic press at 
$1.2 \mathrm{kPa}$ for $1 \mathrm{~h}$, followed by $2.4 \mathrm{kPa}$ for $3 \mathrm{~h}$. Cheeses were salted by immersion in brine $(19 \% \mathrm{NaCl})$ for $2 \mathrm{~h}$, and ripened in a room at $14^{\circ} \mathrm{C}$ and $85 \%$ relative humidity for $60 \mathrm{~d}$. Fresh cheese yield (CHY) was expressed as kilograms of cheese per $100 \mathrm{~kg}$ of milk, and samples for chemical analysis were collected on d 1, 15, 30, and 60 after manufacturing.

\section{Coagulation Properties}

During cheese manufacturing, coagulation was monitored with a Gelograph probe (Gelograph-NT, Gel-Instrumente, Thalwil, Switzerland) and values for rennet clotting time (RCT), rate of curd aggregation (RCA), and gel firmness at $30 \mathrm{~min}\left(\mathbf{F}_{\mathbf{3 0}}\right)$ were obtained. Rennet clotting time is the time ( $\mathrm{min}$ ) elapsed between the addition of rennet and the formation of the first aggregates detected by the instrument; RCA describes micellar aggregation and corresponds to the slope value obtained by linear regression expressed as percentage of transmission $(\mathbf{T})$ per minute $(\% \mathrm{~T} / \mathrm{min})$; and $\mathrm{F}_{30}(\Delta \% \mathrm{~T})$ is the curd firmness after 30 min of coagulation.

\section{Cheese Composition}

Cheeses were analyzed at $60 \mathrm{~d}$ of ripening in triplicate for TS (IDF, 1982), fat by using the Van Gulik method (ISO, 1975), and total nitrogen (TN; IDF, 2002), and $\mathrm{pH}$ was measured in duplicate with a $\mathrm{pH}$ meter (Crison Micro-pH, Crison Instruments SA) on a cheese/distilled water slurry (1:1, by weight).

\section{Water-Soluble Nitrogen and Total Free Amino Acids Analysis}

Water-soluble nitrogen at $\mathrm{pH} 4.6$ (WSN) was performed following the procedure described by Kuchroo and Fox (1982) and expressed as percentage of TN, whereas total free amino acids (FAA) were determined according to the method described by Folkertsma and Fox (1992). These 2 parameters were used as an index of proteolysis and were measured at 1, 15, 30, and 60 $\mathrm{d}$ of ripening.

\section{Free Fatty Acids Analysis}

Sample cheeses for FFA determinations were stored at $-70^{\circ} \mathrm{C}$ until defrosted at $4^{\circ} \mathrm{C}$ for $24 \mathrm{~h}$ before analysis. Analysis of FFA was conducted in duplicate for cheeses with 15, 30, and $60 \mathrm{~d}$ of ripening. Extraction was performed according to the procedure of De-Jong and Badings (1990) with some modifications. Cheese $(1 \mathrm{~g})$ was weighed in a screw-capped glass tube with 3 $\mathrm{g}$ of anhydrous $\mathrm{Na}_{2} \mathrm{SO}_{4}$, and $0.3 \mathrm{~mL}$ of $\mathrm{H}_{2} \mathrm{SO}_{4}(2.5 \mathrm{M}$ ), and $30 \mu \mathrm{L}$ of internal standard solution in diethyl ether (heptanoic acid, $36.4 \mathrm{mg} / \mathrm{mL}$ ) was added. A volume of $3 \mathrm{~mL}$ of diethyl ether-heptane (1:1 vol/vol) was added, and the mixture was shaken on a vortex mixer for 3 min. The resulting supernatant was transferred to another tube containing $1 \mathrm{~g}$ of anhydrous $\mathrm{Na}_{2} \mathrm{SO}_{4}$. This procedure was repeated 3 times and the collected lipid extract was loaded onto a conditioned $(10 \mathrm{~mL}$ of heptanes) aminopropyl column (Spe-ed $\mathrm{NH}_{2} 500 \mathrm{mg} / \mathrm{mL}$, Applied Separations, Allentown, PA). Glycerides in the lipid extraction were removed with $20 \mathrm{~mL}$ of hexane/2propanol $(3: 2 \mathrm{vol} / \mathrm{vol})$, and FFA were eluted with $5 \mathrm{~mL}$ of diethyl ether containing $2 \%$ formic acid. The quantification of each FFA was carried out by direct injection of the solution $(1 \mu \mathrm{L})$ into the gas chromatograph (GCSystem HP 6890 Series, Waldbronn, Germany). An automatic on-column injector (HP 6890) and a flameionization detector were used. Separation occurred in a fused silica capillary column $(30 \mathrm{~m} \times 0.25 \mathrm{~mm} \times 0.25$ $\mu \mathrm{m}$; Teknokroma TRB-5TR, Teknokroma, Barcelona, Spain), and high-purity helium $(0.9 \mathrm{~mL} / \mathrm{min})$ was used as the carrier gas. Oven temperature was increased from 50 to $240^{\circ} \mathrm{C}$ at a rate of $5^{\circ} \mathrm{C} / \mathrm{min}$ and maintained for 20 min. Individual FFA were identified by comparing their retention times with those of the commercial standards (Sigma Chemical Company, St. Louis, MO). Different standard mixtures with increasing concentrations of individual FFA and fixed concentrations of heptanoic acid as internal standard $(\mathrm{C} 7 ; 0.7 \mu \mathrm{g} / \mathrm{mL})$ were used for the calculation of calibration curves.

\section{Sensory Analysis}

The overall sensory evaluation of cheeses was carried out by a group of 8 panelists from our laboratories. Each panelist was experienced with dairy products and in the sensory assessment of cheeses. Cheeses were sampled and tested at $60 \mathrm{~d}$ of ripening. A wedge $(1 \mathrm{~cm}$ thick) of cheese was cut and the rind was removed. To evaluate the overall sensory impression of each cheese, all samples were rated on a 7-point scale in which 0 corresponded to "defective" and 7 corresponded to "excellent."

\section{Statistical Analysis}

Data analysis was carried out by using the SAS statistical program (version 9.1, SAS Institute Inc., Cary, NC). Somatic cell count values were converted into logarithm to perform the statistical analysis. Differences between diets were tested by an ANOVA performing a PROC GLM for each ripening time. The cheese production and the diet were considered the main factors and the evaluations were based on a significance level of $P<0.05$. 
Table 2. Physicochemical characteristics and SCC of cheese milk corresponding to experimental rations with $0,10,20$ and $30 \%$ of citrus fruits $(\mathrm{CF})($ means $\pm \mathrm{SD})$

\begin{tabular}{lcccc}
\hline & & \multicolumn{3}{c}{ Ration } \\
\cline { 2 - 5 } Parameter & $0 \%$ CF & $10 \%$ CF & $20 \%$ CF & $30 \%$ CF \\
\hline Fat (\%) & $7.92 \pm 0.23^{\mathrm{a}}$ & $8.42 \pm 0.48^{\mathrm{a}}$ & $7.88 \pm 0.14^{\mathrm{a}}$ & $6.75 \pm 0.44^{\mathrm{b}}$ \\
Protein (\%) & $6.41 \pm 0.40$ & $7.02 \pm 0.48$ & $6.78 \pm 0.38$ & $6.64 \pm 0.07$ \\
CN (\%) & $5.13 \pm 0.32$ & $5.62 \pm 0.36$ & $5.44 \pm 0.32$ & $5.32 \pm 0.05$ \\
Lactose (\%) & $4.56 \pm 0.06^{\mathrm{a}}$ & $4.34 \pm 0.04^{\mathrm{b}}$ & $4.38 \pm 0.05^{\mathrm{b}}$ & $4.54 \pm 0.02^{\mathrm{a}}$ \\
Total solids (\%) & $19.82 \pm 0.66^{\mathrm{ab}}$ & $20.76 \pm 0.99^{\mathrm{a}}$ & $20.01 \pm 0.43^{\mathrm{ab}}$ & $18.87 \pm 0.40^{\mathrm{b}}$ \\
pH (SCC) & $6.40 \pm 0.09$ & $6.51 \pm 0.10$ & $6.47 \pm 0.07$ & 5.13 \\
Log (S. & $5.21 \pm 0.12^{\mathrm{b}}$ & $5.24 \pm 0.10^{\mathrm{b}}$ & $5.16 \pm 0.13^{\mathrm{b}}$ \\
\hline
\end{tabular}

${ }^{\mathrm{a}, \mathrm{b}}$ Means in the same row followed by different letters differ significantly $(P<0.05)$.

\section{RESULTS AND DISCUSSION}

\section{Cheese Milk Composition}

Physicochemical composition and SCC of milk used for cheese making is presented in Table 2. Differences between milks were significant for fat, lactose, and total solids $(P<0.05)$. Milk corresponding to diet with $30 \%$ CF showed $15 \%$ less fat and almost $5 \%$ less total solids compared with control milk. On the other hand, cheese milks from citrus rations showed a nonsignificant trend to have greater protein content.

Similar composition had been observed by Piquer (2006), who studied the effect of including whole citrus in the ration of dairy ewes on the composition of milk, analyzing a large number of samples during the lactation period. The results obtained showed that the use of $30 \%$ whole citrus fruits in the diet leads to a reduction of the milk fat content, whereas greater protein content corresponded to the milk from ewes fed with $10 \%$ citrus in the ration.

Further work related to the use of fresh citrus (Volcani, 1956) and dry citrus pulp (Belibasakis and Tsirgogianni, 1996) in the diet of dairy cows showed that these rations increased the fat content of milk but did not affect the protein content. This milk fat increase was also observed in dairy ewes fed with ensiled oranges at levels of $79 \%$ in a fresh matter basis; along with this effect, a $3 \%$ reduction of milk protein content was also described (Volanis et al., 2004). In contrast to these results, Fegeros et al. (1995), who evaluated the use of dry citrus pulp (11\%) in the ration of dairy ewes, did not observe any significant effect of diet on the composition of milk.

\section{Coagulation Parameters and Cheese Composition}

Milk coagulation parameters were similar for all cheese milk samples regarding the ration fed to dairy ewes. Only the higher curd firmness observed in 30\% CF ration was significantly different from the other cheese milk samples (Table 3). This result may be explained by the lower milk fat content of this sample, because it has been observed from previous experiments that a high fat content in ewe milk could impair curd formation (Jaramillo et al., 2008).

Cheese yield did not differ significantly between rations. However, it was possible to observe a reduction in cheese yield when ewes were fed rations with 20 and $30 \% \mathrm{CF}$. The ration with $10 \% \mathrm{CF}$ showed the highest value for cheese yield, probably because of the major content of total solids, protein, and casein, which are components directly correlated with yield (Soryal et al., 2005).

Differences between rations in relation to cheese composition at the end of ripening were significant $(P$ $<0.05)$ for TS and fat content (Table 4). Cheeses corre-

Table 3. Coagulation parameters and cheese yield obtained during cheese manufacture corresponding to experimental rations with 0 , 10, 20, and $30 \%$ of citrus fruits $(\mathrm{CF})$ (means $\pm \mathrm{SD}$ )

\begin{tabular}{lcccc}
\hline & \multicolumn{3}{c}{ Ration } \\
\cline { 2 - 5 } Parameter $^{1}$ & $0 \% \mathrm{CF}$ & $10 \% \mathrm{CF}$ & $20 \% \mathrm{CF}$ & \multicolumn{1}{c}{$30 \% \mathrm{CF}$} \\
\hline $\mathrm{RCT}(\min )$ & $11.45 \pm 1.43$ & $12.24 \pm 0.58$ & $11.13 \pm 1.40$ & $11.37 \pm 1.44$ \\
$\mathrm{~F}_{30}(\Delta \% \mathrm{~T})$ & $3.09 \pm 0.38^{\mathrm{ab}}$ & $2.81 \pm 0.24^{\mathrm{b}}$ & $2.80 \pm 0.31^{\mathrm{b}}$ & $3.64 \pm 0.31^{\mathrm{a}}$ \\
$\mathrm{RCA}(\% \mathrm{~T} / \mathrm{min})$ & $0.45 \pm 0.08$ & $0.42 \pm 0.05$ & $0.41 \pm 0.08$ & $0.58 \pm 0.11$ \\
$\mathrm{CHY}(\%)$ & $30.07 \pm 3.50$ & $31.32 \pm 2.89$ & $27.58 \pm 1.97$ & $25.88 \pm 2.04$ \\
\hline
\end{tabular}

${ }^{\mathrm{a}, \mathrm{b}}$ Means in the same row followed by different letters differ significantly $(P<0.05)$.

${ }^{1} \mathrm{RCT}=$ rennet clotting time; $\mathrm{F}_{30}=$ gel firmness; $\mathrm{RCA}=$ rate of curd aggregation; $\mathrm{CHY}=$ cheese yield . 

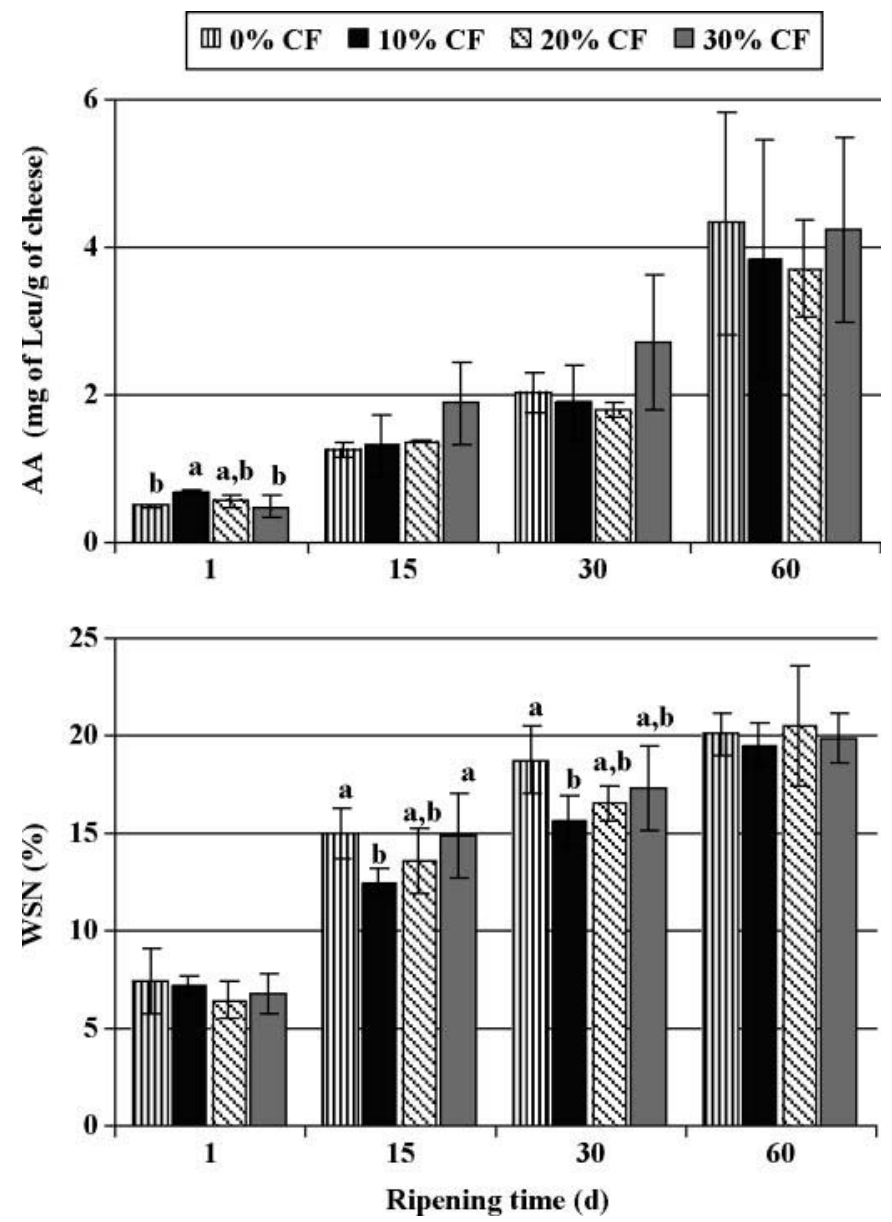

Figure 1. Total free amino acids (AA) and water-soluble nitrogen (WSN, expressed as percentage of total nitrogen) of cheeses at each ripening stage (means $\pm \mathrm{SD}$ ), corresponding to experimental rations with $0,10,20$, and $30 \%$ of citrus fruits $(\mathrm{CF})$. ${ }^{\mathrm{a}, \mathrm{b}}$ Means with different letters within the same ripening time are significantly different $(P<$ $0.05)$.

sponding to $30 \% \mathrm{CF}$ rations showed less TS and about $13 \%$ less fat than $0 \% \mathrm{CF}$ cheeses. These differences can be explained by the cheese milk composition (Table 2). Despite differences, control and experimental cheeses showed a similar composition to that described for ewe milk cheese (Pavia et al., 1999).

\section{Proteolysis: WSN and AA Content}

The increase of FAA and WSN from the day of manufacture to the end of ripening $(60 \mathrm{~d})$ was similar for all cheese samples (Figure 1). Initial values for FAA ranged from 0.5 to 0.7 and increased up to 3.7 to 4.3 $\mathrm{mg}$ of leucine per $\mathrm{g}$ of cheese. The WSN accounted for 6.4 to $7.4 \%$ by d 1 , reaching 19.5 to $20.5 \%$ at $60 \mathrm{~d}$ of ripening. These values were similar to those described for Manchego-type cheeses manufactured from pasteurized milk and coagulated by commercial rennet (Juan et al., 2007).

Statistical differences between diets were significant for the lower WSN value observed in $10 \% \mathrm{CF}$ cheeses at 15 and $30 \mathrm{~d}$ of ripening and for the content of $\mathrm{AA}$ of these cheeses at the first day of ripening. However, AA and WSN content of cheeses were not affected by the inclusion of citrus in the rations at $60 \mathrm{~d}$ of ripening. Proteolysis is an important biochemical event of ripened cheeses that is highly influenced by factors such as season of manufacture (Muñoz et al., 2003; Gaya et al., 2005 ), enzymatic activity of the rennet used (Irigoyen et al., 2001), and the addition of high aminopeptidic starters or peptidases (Garde et al., 2006). Published studies regarding the effect of diet on the proteolysis of cheeses is scarce. However, Bugaud et al. (2001) observed differences in the plasmid activity and primary proteolysis of cheeses between dairy cows grazing different types of pastures. In contrast, Verdier-Metz et al. (2005) did not report differences in the formation of soluble nitrogen of cheeses (Cantal and Saint-Nectaire) corresponding to cows fed either grass silage or hay diet. Similar results were observed by Cavani et al. (1991), who evaluated the effect of feeding lactating ewes with a traditional diet based on hay and commercial feed versus a complete diet composed mainly of maize silage, showing that ewe diet had no effect on the soluble nitrogen content of ripened cheeses.

Table 4. Mean values and standard deviations of cheese composition at $60 \mathrm{~d}$ of ripening corresponding to experimental rations with $0,10,20$, and $30 \%$ of citrus fruits $(\mathrm{CF})$

\begin{tabular}{lcccc}
\hline & \multicolumn{3}{c}{ Ration } \\
\cline { 2 - 5 } Parameter $^{1}$ & $0 \%$ CF & $10 \%$ CF & $20 \%$ CF & $30 \%$ CF \\
\hline TS (\%) & $70.57 \pm 0.84^{\mathrm{a}}$ & $69.61 \pm 1.44^{\mathrm{a}}$ & $70.79 \pm 1.89^{\mathrm{a}}$ & $67.83 \pm 3.33^{\mathrm{b}}$ \\
TN (\% of TS) & $5.79 \pm 0.06$ & $5.76 \pm 0.34$ & $5.74 \pm 0.47$ & $5.99 \pm 0.64$ \\
Fat (\% of TS) & $55.95 \pm 2.71^{\mathrm{a}}$ & $54.58 \pm 1.96^{\mathrm{a}}$ & $54.61 \pm 2.28^{\mathrm{a}}$ & $50.71 \pm 3.73^{\mathrm{b}}$ \\
pH & $4.90 \pm 0.04^{\mathrm{a}}$ & $4.87 \pm 0.06^{\mathrm{a}}$ & $4.81 \pm 0.05^{\mathrm{b}}$ & $4.90 \pm 0.03^{\mathrm{a}}$ \\
\hline
\end{tabular}

${ }^{\mathrm{a}, \mathrm{b}}$ Means in the same row followed by different letters differ significantly $(P<0.05)$.

${ }^{1} \mathrm{TS}=$ total solids; $\mathrm{TN}=$ total nitrogen. 
(A)

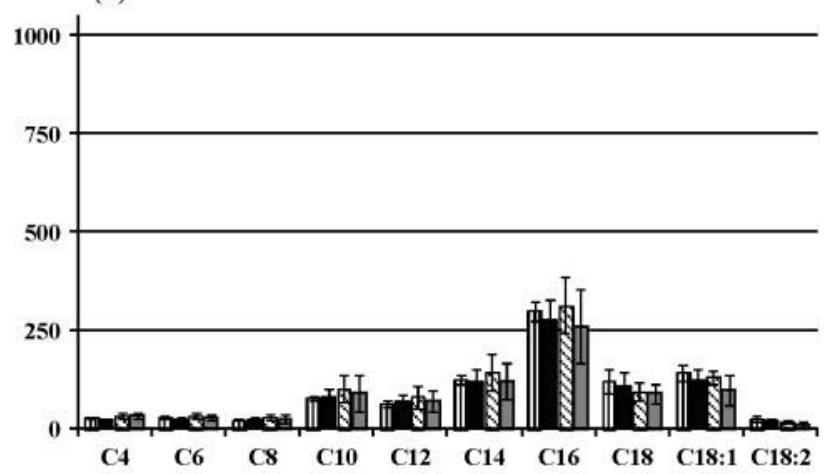

(B)
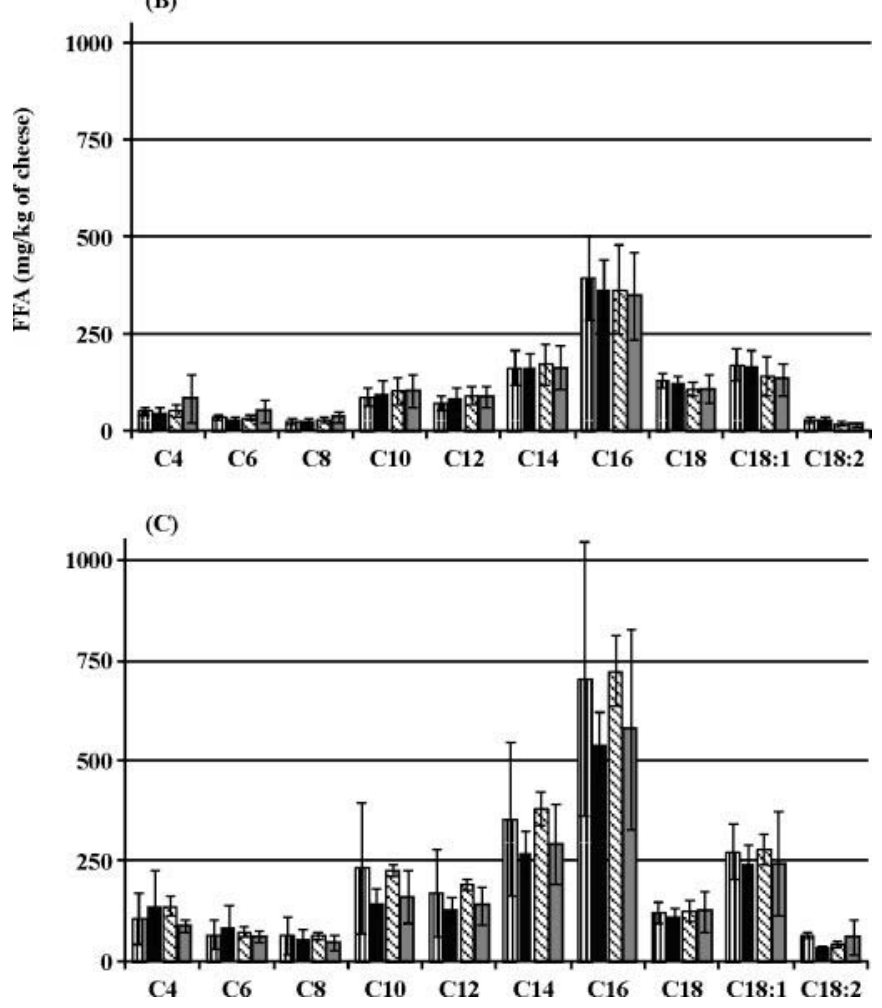

Figure 2. Individual free fatty acids (FFA) of cheeses with 15 (A), $30(\mathrm{~B})$, and $60(\mathrm{C})$ days of ripening corresponding to experimental rations with $0,10,20$, and $30 \%$ of citrus fruits $(\mathrm{CF})$ (means $\pm \mathrm{SD}$ ).

\section{Lipolysis: FFA Content}

Free fatty acid evolution of cheeses corresponding to the experimental rations is shown in Figure 2. Individual FFA concentrations increased significantly during ripening $(P<0.05)$, except that the stearic acid of $10 \%$ $\mathrm{CF}$ cheeses remain unchanged during this period. The significant effect of time on the formation of FFA is a common characteristic among ripened cheeses made from ewe, goat, or cow milk (Mallatou et al., 2003; Fernández-García et al., 2006).
The most abundant FFA observed in cheeses, irrespective of ripening time and feeding treatment, were myristic, palmitic, and oleic acids (with individual percentages of 15,32 , and $13 \%$ of total FFA), and butyric acid was the main short-chain FFA found in cheeses after $30 \mathrm{~d}$ of ripening (4-8\% of total FFA). Similar FFA profile was described by other researchers for ewe milk ripened cheeses (Poveda et al., 2000; Fernández-García et al., 2006).

At $15 \mathrm{~d}$ of ripening, significant differences between cheeses were observed for all individual FFA $(P<0.05)$. However, when individual data were grouped in short-, medium-, and long-chain FFA (Table 5) only this last parameter differed significantly $(P<0.05)$ between rations, so that cheeses corresponding to $\mathrm{CF}$ rations showed a lower content of long-chain FFA compared with the $0 \% \mathrm{CF}$ ration. Individual $\mathrm{FFA}$ differences remained significant in 30-d cheeses except for butyric and caproic acids. At this ripening time, total values for FFA groups did not differ significantly; however, the content of long-chain FFA showed the same trend described previously. Cheeses at $60 \mathrm{~d}$ of ripening showed greater differences for most of the individual FFA except for butyric acid. These differences did not describe a specific trend related to the increasing amount of $\mathrm{CF}$ in the rations and differed from the trends observed at 15 and $30 \mathrm{~d}$ (Table 5). Thus, the $10 \% \mathrm{CF}$ cheeses presented lower levels of medium- and long-chain FFA and therefore the lowest content of total FFA, whereas cheeses corresponding to $0 \%$ and $20 \% \mathrm{CF}$ in the diet presented similar concentrations of short-, medium-, and long-chain FFA. Differences of FFA between 60-d cheeses could be partially explained by their original fat content. Cheeses corresponding to the $0 \% \mathrm{CF}$ ration showed higher fat percentage $(55.9 \%)$, whereas $30 \% \mathrm{CF}$ cheeses presented the lowest $(50.7 \%)$ and therefore a lower FFA content. It is known that milk fat composition is influenced by diet; therefore, it may have an impact on cheese FFA concentration. In this sense, Rodríguez et al. (2006) evaluated the effect of including whole citrus fruits in the rations of dairy ewes on milk fat composition and described that citrus rations increased the short-chain FFA and decreased long-chain FFA, whereas medium-chain FFA remained unchanged.

Relative percentages of FFA changed during the ripening period. Short-chain FFA were between 9 and $13 \%$ of the total FFA, and tended to increase except in $30 \%$ CF cheese, which showed a decrease in short-chain FFA at $60 \mathrm{~d}$ of ripening (probably due to metabolization of short-chain FFA into other volatile components). Medium-chain FFA represented 25 to $37 \%$ of all FFA; this group of FFA also tended to increase with ripening except in the $10 \%$ CF cheeses. Finally, long-chain FFA accounted for 43 to $54 \%$ of the total FFA and showed 
a decrease in their percentage with the advance of the ripening period. Despite their higher concentration, long-chain FFA do not contribute to cheese flavor like short-chain FFA do. The evolution of these ratios agrees with that described by Fernández-García et al. (2006) for ewe milk cheeses such as Manchego and Zamorano. Despite the small differences between the experimental rations, all cheeses showed a good FFA balance. According to Fernández-García et al. (1994) this balance is described by the ratio $\Sigma(\mathrm{C} 4-\mathrm{C} 10) / \Sigma(\mathrm{C} 12-\mathrm{C} 18)$ and should be within the range of 30 to $50 \%$ to avoid the development of abnormal off-flavors in ripened cheese. Irrespective of the feeding ration, our cheeses presented normal and similar ratios (0\% CF: $34.9 ; 10 \% \mathrm{CF}: 40.5$; 20\% CF: 35.4 and 30\% CF: 31.8).

\section{Sensory Analysis}

Overall impression rated by the taste panel showed similar scores for all cheeses irrespective of the level of $\mathrm{CF}$ in the rations. All cheeses presented values close to 4 in the 7-point scale used, and did not show significant differences $(0 \% \mathrm{CF}=3.98 \pm 1.39 ; 10 \% \mathrm{CF}=4.04 \pm$ $1.20 ; 20 \% \mathrm{CF}=3.77 \pm 1.46$, and $30 \% \mathrm{CF}=4.27 \pm$ 1.36). The lack of differences agrees with the similar content and evolution of the proteolytic parameters observed during ripening. According to Fernández-García et al. (1994), cheese proteolysis plays a greater role in the development of Manchego cheese flavor than other biochemical changes such as the formation of FFA. The inclusion of $\mathrm{CF}$ in the ration of dairy ewes up to the level of 30\% (DM basis) did not affect the overall sensory quality of cheeses.

\section{CONCLUSIONS}

In this study, the increasing substitution of barley in the diet of lactating ewes with levels up to $30 \%$ of citrus fruits produced minor changes in milk parameters. The highest level of $\mathrm{CF}$ in the ration reduces the bulk milk fat and total solids content by 15 and $5 \%$, respectively. Despite this effect on milk composition, CF does not impair milk coagulation properties. The physicochemical and biochemical changes of cheeses during ripening were slightly influenced by these experimental diets as is reflected by the similar WSN, FAA, and total FFA content of cheeses. The same can be concluded for the overall sensory evaluation of $60-d$ cheeses, which received positive and similar scores from the panelists.

\section{ACKNOWLEDGMENTS}

The authors acknowledge the Ministerio de Ciencia y Tecnología for the financial support given to this 
investigation (INIA CAL 03-089). Diana P. Jaramillo acknowledges a research assistantship from the Centre Especial de Recerca Planta de Tecnologia dels Aliments (CERPTA).

\section{REFERENCES}

Bampidis, V. A., and P. H. Robinson. 2006. Citrus by-products as ruminant feeds: A review. Anim. Feed Sci. Technol. 128:175217.

Belibasakis, N. G., and D. Tsirgogianni. 1996. Effects of dried citrus pulp on milk yield, milk composition and blood components of dairy cows. Anim. Feed Sci. Technol. 60:87-92.

Bugaud, C., S. Buchin, Y. Noel, L. Tessier, S. Pochet, B. Martin, and J. F. Chamba. 2001. Relationships between Abondance cheese texture, its composition and that of milk produced by cows grazing different types of pastures. Lait 81:593-607.

Cavani, C., L. Bianconi, M. Manfredini, L. Rizzi, and M. C. Zarri 1991. Effects of a complete diet on the qualitative characteristics of ewe milk and cheese. Small Rumin. Res. 5:273-284.

Coulon, J. B., A. Delacroix-Buchet, B. Martin, and A. Pirisi. 2004 Relationships between ruminant management and sensory characteristics of cheeses: A review. Lait 84:221-241.

De-Jong, C., and H. Badings. 1990. Determination of free fatty acids in milk and cheese. Procedures for extraction clean up and capillary gas chromatographic analysis. J. High Resolut. Chromatogr. 13:94-98.

FAOSTAT. 2006. FAOSTAT data 2006. http://faostat.fao.org. Accessed Feb. 20, 2008.

Fegeros, K., G. Zervas, S. Stamouli, and E. Apostolaki. 1995. Nutritive value of dried citrus pulp and its effect on milk yield and milk composition of lactating ewes. J. Dairy Sci. 78:1116-1121.

Fernández-García, E., M. Carbonell, J. Calzada, and M. Núñez. 2006. Seasonal variation of the free fatty acids contents of Spanish ovine milk cheeses protected by a designation of origin: A comparative study. Int. Dairy J. 16:252-261.

Fernández-García, E., R. López-Fandino, and L. Alonso. 1994. Effect of a food-grade enzyme preparation from Aspergillus oryzae on free fatty acid release in Manchego-type cheese from ovine and bovine milk. Z. Lebensm. Unters. Forsch. 99:262-264.

Folkertsma, B. B., and B. P. Fox. 1992. Use of the cd-ninhydrin reagent to assess proteolysis in cheese during ripening. J. Dairy Res. 59:217-224.

Garde, S., M. Avila, P. Gaya, M. Medina, and M. Núñez. 2006. Proteolysis of Hispanico cheese manufactured using lacticin 481-producing Lactococcus lactis ssp. lactis INIA 639. J. Dairy Sci. 89:840-849.

Gaya, P., C. Sánchez, M. Núñez, and E. Fernández-García. 2005. Proteolysis during ripening of Manchego cheese made from raw or pasteurized ewes' milk. Seasonal variation. J. Dairy Res. 72:287295.

IDF. 1982. Cheese and processed cheese. Determination of the total solids content. IDF Standard 4A. International Dairy Federation, Brussels, Belgium.

IDF. 1996. Whole milk, determination of milkfat, protein and lactose content. Guidance on the operation of mid-infrared instruments. IDF Standard 141C. International Dairy Federation, Brussels, Belgium.

IDF. 2002. Milk and milk products. Determination of the nitrogen content. Routine method using combustion according to the Dumas principle. IDF Standard 185. International Dairy Federation, Brusells, Belgium.
Irigoyen, A., J. M. Izco, F. C. Ibáñez, and P. Torre. 2001. Influence of rennet milk-clotting activity on the proteolytic and sensory characteristics of an ovine cheese. Food Chem. 72:137-144.

ISO. 1975. Cheese-Determination of fat content-Van Gulic method. ISO Standard 3433. International Standards Organization, Leusden, the Netherlands.

Jaramillo, D., A. Zamora, B. Guamis, M. Rodríguez, and A.J. Trujillo. 2008. Cheesemaking aptitude of two Spanish dairy ewe breeds: Changes during lactation and relationship between physicochemical and technological properties. Small Rumin. Res. 78:4855 .

Juan, B., V. Ferragut, M. Buffa, B. Guamis, and A. J. Trujillo. 2007. Effects of high pressure on proteolytic enzymes in cheese: Relationship with the proteolysis of ewe milk cheese. J. Dairy Sci. 90:2113-2125.

Kuchroo, C. N., and P. F. Fox. 1982. Soluble nitrogen in Cheddar cheese: Comparison of extraction procedures. Milchwissenschaft $37: 331-335$.

Mallatou, H., E. Pappa, and T. Massouras. 2003. Changes in free fatty acids during ripening of Teleme cheese made with ewes', goats', cows' or a mixture of ewes' and goats' milk. Int. Dairy J. 13:211-219

Muñoz, N., M. Ortigosa, P. Torre, and J. M. Izco. 2003. Free amino acids and volatile compounds in a ewe's milk cheese as affected by seasonal and cheese-making plant variations. Food Chem. 83:329-338.

Pavia, M., B. Guamis, A. J. Trujillo, M. Capellas, and V. Ferragut 1999. Changes in microstructural, textural and colour characteristics during ripening of Manchego-type cheese salted by brine vacuum impregnation. Int. Dairy J. 9:91-98.

Piquer, O. 2006. Whole citrus fruits in sheep nutrition, Spain. PhD Thesis. Universidad Politécnica de Valencia, Valencia, Spain.

Poveda, J. M., M. S. Pérez-Coello, and L. Cabezas. 2000. Seasonal variations in the free fatty acid composition of Manchego cheese and changes during ripening. Eur. Food Res. Technol. 210:314317.

Rodríguez, M., M. Beltrán, M. Tomás, O. Piquer, P. Molina, and J. Pascal. 2006. Efecto de la incorporación de cítricos de destrío en la ración de ovejas lactantes sobre el contenido de grasa de la leche y su composición en ácidos grasos. Pages $35-37$ in Proc. XXXI Jornadas Científicas y X Internacionales SEOC, Zamora, Spain.

Soryal, K., F. A. Beyene, S. Zeng, B. Bah, and K. Tesfai. 2005. Effect of goat breed and milk composition on yield, sensory quality, fatty acid concentration of soft cheese during lactation. Small Rumin. Res. 58:275-281.

Trujillo, A. J., C. Royo, B. Guamis, and V. Ferragut. 1999. Influence of pressurization on goat milk and cheese composition and yield. Milchwissenschaft 54:197-199.

Urbach, G. 1990. Effect of feed on flavor in dairy foods. J. Dairy Sci. 73:3639-3650.

Verdier-Metz, I., B. Martin, P. Pradel, H. Albouy, S. Hulin, M. C. Montel, and J. B. Coulon. 2005. Effect of grass-silage vs. hay diet on the characteristics of cheese: Interactions with the cheese model. Lait 85:469-480.

Volanis, M., P. Zoiopoulos, and K. Tzerakis. 2004. Effects of feeding ensiled sliced oranges to lactating dairy sheep. Small Rumin. Res. $53: 15-21$.

Volcani, R. 1956. A survey of the use of citrus fruit and waste for feeding dairy cattle in Israel. Ktavim 6:135-147. 